\title{
Post intrastromal corneal ring segments insertion complicated by Candida parapsilosis keratitis
}

This article was published in the following Dove Press journal:

Clinical Ophthalmology

27 February 2013

Number of times this article has been viewed

Bradley M Mitchell'

A John Kanellopoulos ${ }^{2}$

Ramon L Font ${ }^{3}$

'Eclipse IS Consulting, Rosenberg, TX, ${ }^{2}$ Department of Ophthalmology,

New York University Medical School, New York City, NY, ${ }^{3}$ Department of Ophthalmology, Ophthalmic Pathology Laboratory, Cullen Eye Institute, Baylor College of Medicine, Houston, TX, USA
Correspondence: Bradley M Mitchell Eclipse IS Consulting, 31 I8 Andell Ridge Rd, Rosenberg, TX 7747I, USA

Tel + I 28I 9235406

Fax + | 28| 49| 4927

Email mitchellmiranda@earthlink.net

\begin{abstract}
This case report describes the clinical and histopathologic features, including molecular confirmation, of fungal keratitis after intrastromal corneal ring segments placement for keratoconus. A 52-year-old woman underwent insertion of Intacs $^{\circledR}$ corneal implants for treatment of keratoconus. Extrusion of the implants was noted 5 months post insertion and replaced. Three months later, monocular infiltrates and an epithelial defect were observed. The Intacs were removed and the infiltrates were treated with ofloxacin and prednisolone acetate. Microbial cultures and stains were negative. The patient demonstrated flares and exacerbation one month later. Mycoplasma and/or fungus were suspected and treated without improvement. Therapeutic keratoplasty was performed 10 months following initial placement of the corneal ring implants. The keratectomy specimen was analyzed by light microscopy and a panfungal polymerase chain reaction assay. A histopathologic diagnosis of Candida parapsilosis keratitis was made and confirmed by polymerase chain reaction. One year postoperatively, a systemic workup of the patient was done with no signs of recurrence. This rare report of fungal keratitis following Intacs insertion is the first reported case of $C$. parapsilosis complicating Intacs implantation.
\end{abstract}

Keywords: keratoconus, Intacs ${ }^{\circledR}$, polymerase chain reaction, PCR, molecular diagnosis, histopathology

\section{Introduction}

Intacs $^{\circledR}$ (Addition Technology Inc, Des Plaines, IL, USA) are intrastromal corneal rings consisting of two thin, clear hexagonal polymethyl methacrylate segments. They are placed in surgically created semicircular channels between the stromal lamella at two-thirds the stromal depth during an outpatient procedure. Intrastromal ring segments work by flattening the central corneal curvature, and are adjustable and reversible. Since receiving approval by the US Food and Drug Administration in 1999, they have been used to correct low to moderate myopia ${ }^{1}$ and to treat ectasia following laser in situ keratomileusis. ${ }^{2}$ Asymmetric implantation of intrastromal corneal ring segments in eyes with keratoconus has been demonstrated to improve both uncorrected and best spectacle-corrected visual acuity, and to reduce irregular astigmatism in corneas with and without scarring. ${ }^{3-7}$

Relatively few infectious complications have been reported with the use of the intrastromal corneal segments; channel infections have been infrequently documented, ${ }^{1,8-10}$ and only a limited number of infectious keratitis cases have been reported following insertion of Intacs. ${ }^{8,9,11-16}$ Although uncommon, microbial keratitis following intrastromal corneal segments insertion is potentially one of the most serious complications and may be sight-threatening. Appropriate suspicion by the 
eye care provider along with rapid diagnosis and appropriate management can be critical and result in improved visual recovery.

The purpose of this study was to describe the clinical and pathologic features of Candida parapsilosis keratitis, which occurred 8 months following the initially uneventful placement of Intacs inserts for keratoconus. This is the first report in the peer-reviewed literature of $C$. parapsilosis following Intacs insertion and includes molecular confirmation at the species level.

\section{Case report}

The patient was a 52-year-old female with a history of keratoconus and no known systemic disease or risk factors for infection. Preoperatively, the patient had uncorrected visual acuity of 20/60 OD and 20/200 OS, and best-corrected visual acuity of 20/30 OD and 20/50 OS, with a refraction of $-3.00-3.50 \times 170$ degrees OD and $-5.50-4.50 \times 20$ degrees OS. Intacs intrastromal corneal ring segments were vertically placed in her left eye for treatment of her keratoconus. Specifically, a 35 ring was inserted superiorly and a 45 ring inferiorly through a $65 \%-70 \%$ depth channel. Good visual rehabilitation was obtained following Intacs insertion (uncorrected visual acuity, OS 20/40; best-corrected visual acuity OS 20/25) and was uneventful at 4 months post insertion (Figure 1A).
Spontaneous extrusion of the inferior intrastromal corneal ring segment with no indication of infection was noted 5 months after insertion (Figure 1B), at which time it was removed. The channel was infused with vancomycin solution and a new ring segment was inserted. Eight months post Intacs implantation ( 3 months post replacement), the location of the lower lateral edge of the intrastromal corneal ring segments showed an epithelial defect and infiltrate on slit-lamp examination (Figure 1C). The size of the epithelial defect and infiltrate was $1 \mathrm{~mm}$ and the infiltrate was at a depth of $40 \%$. The intrastromal corneal ring segments were removed because of suspected infection and the infiltrate was treated for 2 weeks with topical ofloxacin $0.3 \%$ every 2 hours and prednisolone acetate $1 \%$ once daily. Corneal scrapings cultured on blood agar, chocolate agar, thioglycolate broth, and Sabouraud's agar were negative, as was a Gram stain. The patient was followed weekly and demonstrated flares and exacerbation one month after treatment. The infiltrate progressed into the deep cornea at the level of the intrastromal corneal ring segments at approximately $60 \%$ thickness (Figure 1D). Suspecting mycoplasma and/ or fungus, amphotericin B $0.1 \%$ every 2 hours, vancomycin $10 \mathrm{mg} / \mathrm{mL}$ every 2 hours, and clarithromycin $12 \mathrm{mg} / \mathrm{mL}$ every 2 hours were prescribed for one week without improvement. Therapeutic keratoplasty followed to ensure containment of the infiltrate in the central cornea. Intraoperative

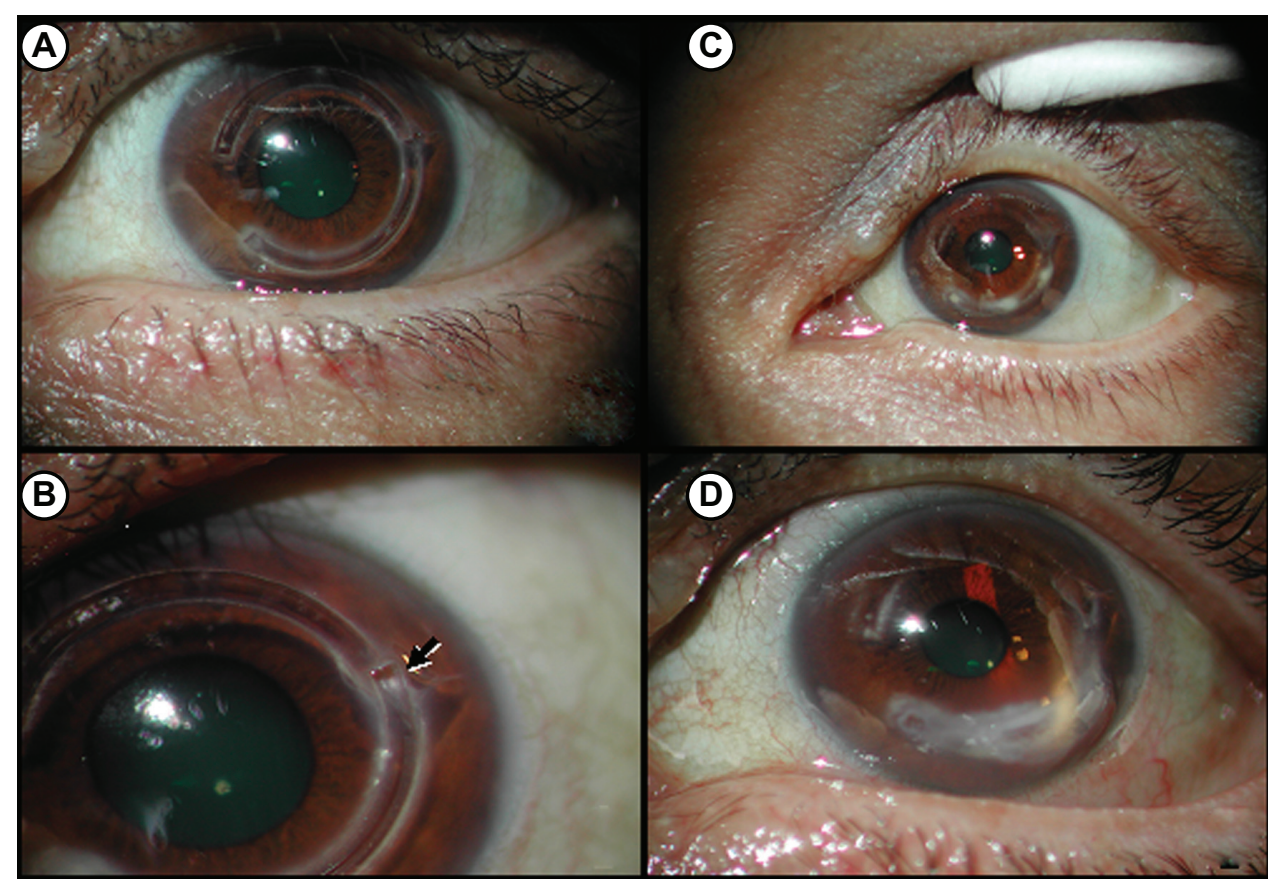

Figure I Slit-lamp photographs of left eye following intrastromal corneal ring segments (Intacs ${ }^{\circledR}$ ) insertion. (A) Four months after Intacs insertion. (B) Spontaneous extrusion of inferior Intacs ring implant (arrow) 5 months following original insertion and prior to ring replacement. (C) Initial stromal infiltrates observed 8 months post Intacs insertion (3 months post replacement). (D) Stromal infiltrates at 10 months after initial Intacs insertion and prior to therapeutic keratoplasty. 
amphotericin and vancomycin were dropped open sky in the anterior chamber.

A formalin-fixed keratectomy specimen was histopathologically examined by light microscopy using standard histopathologic techniques, including periodic acid-Schiff staining. The corneal tissue clearly demonstrated insertion channels for the previously removed intrastromal corneal ring segments and a perforating corneal ulcer (Figure 2). Dense mid-stromal infiltrates and a break in Descemet's membrane were also noted. As seen in the Figure 2 insert, $C$. parapsilosis yeast forms have darker staining central nuclei and produce broad-neck buds.

To confirm the histopathologic findings, the corneal tissue was evaluated using a molecular polymerase chain reaction (PCR)-based diagnostic approach. The forward and reverse panfungal PCR primers encompass a highly conserved region of fungal DNA and are designed to amplify and detect a broad spectrum of fungal DNA without amplifying nonfungal DNA. ${ }^{17}$ The current case report corneal specimen was compared with a previously confirmed ocular case of $C$. parapsilosis-induced infectious crystalline keratopathy, ${ }^{18}$ with DNA isolated from various species of Candida grown in culture (Table 1), and with plasmid pCA1 DNA that contains a relevant fragment of Candida albicans DNA. ${ }^{17}$ Formalin-fixed, paraffin-embedded clinical corneal specimens were cut with a microtome at a thickness of $10 \mu \mathrm{m}$ using precautions necessary for PCR analysis. Twelve to 16 microtome sections were placed into sterile microfuge tubes and the DNA extracted using a protocol previously described ${ }^{19}$ and modified. ${ }^{20}$ Overnight cultures of C. parapsilosis, C. albicans, Candida guilliermondii, and Candida (Yarrowia) lipolytica were grown as described ${ }^{17}$

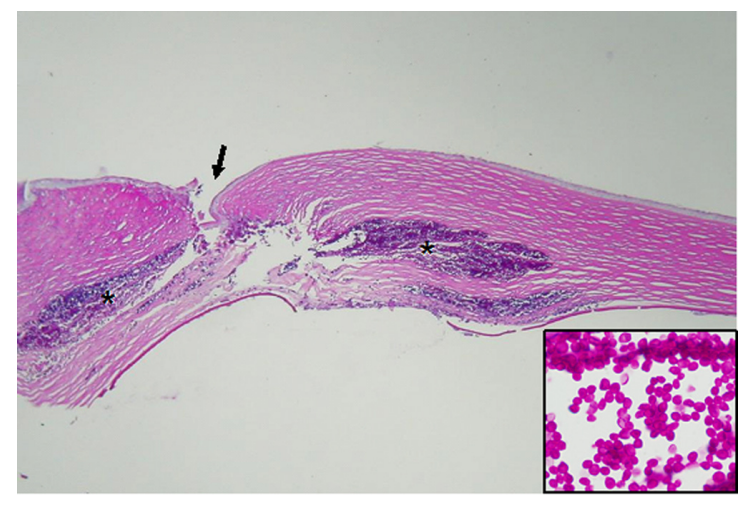

Figure 2 Histopathologic analysis of keratectomy specimen.

Notes: Micrograph of corneal tissue demonstrating a perforating corneal ulcer (arrow) with Intacs ${ }^{\circledR}$ insertion channels (asterisks) and dense mid-stromal infiltrate (periodic acid-Schiff, original magnification 20x). Insert: micrograph of cultured Candida parapsilosis yeast with central nuclei and broad-neck buds (periodic acidSchiff, original magnification $20 \times$ ). and processed for DNA extraction using standard genomic DNA methods ${ }^{21}$ with modifications previously described. ${ }^{17}$ Plasmid pCA1 was grown in Escherichia coli DH5-alpha cells and purified. ${ }^{17}$ Twenty percent of each DNA sample extracted from the clinical specimens was used for PCR analysis. Approximately $1 \times 10^{4}$ genome equivalents of culture-purified DNA from the control Candida strains and $4 \times 10^{4}$ copies of plasmid pCA1 were used as positive control templates. Deionized distilled water was used as a negative PCR control. The PCR assay conditions had been previously optimized and described. ${ }^{17,22,23}$ Twenty percent of each PCR assay product was electrophoretically resolved on $1.8 \%$ agarose Tris-borate-EDTA gel and visualized using ethidium bromide and ultraviolet excitation. PCR amplicons were compared in size with a 50 bp ladder (Life Technologies, Grand Island, NY, USA).

The current keratoplasty specimen produced a PCR amplicon product of approximately $311 \mathrm{bp}$, as did the crystalline keratopathy corneal specimen and the DNA from cultured $C$. parapsilosis (Figure 3 ). The control DNA from cultured C. albicans, C. guilliermondii, and $C$. lipolytica produced amplicons of 338 bp, $379 \mathrm{bp}$, and $242 \mathrm{bp}$, respectively (Figure 3 ) in agreement with the predicted sizes (Table 1). The plasmid pCA1 containing a fragment of $C$. albicans DNA produced the predicted 338 bp PCR product, while the negative control showed no amplification product. The molecular results were in complete concordance with the histopathologic findings and diagnosis. The patient underwent a negative systemic workup, and at one year postoperatively had no signs of recurrence.

\section{Discussion}

Intrastromal corneal ring segments are an option in the management of some patients with keratoconus, and their use has been increasing since their efficacy were first reported by Colin et al..$^{5}$ According to multiple case studies, microbial keratitis occurs as a complication in approximately $1.4 \%-6.8 \%$ of cases post intrastromal ring segments insertion. ${ }^{15,24-26}$ Infectious keratitis following intrastromal corneal ring segments insertion, while uncommon, is potentially one of the most serious complications. Reported microbial species in post-Intacs keratitis include Staphylococcus aureus, Staphylococcus epidermidis, Staphylococcus viridans, Streptococcus pneumoniae, Streptococcus mitis, Pseudomonas species, Nocardia species, Klebsiella species, Paecylomices species, and Clostridium perfringens. ${ }^{8,9,11,12,15}$

Ophthalmologists identified C. parapsilosis as a cause for an epidemic of post-cataract endophthalmitis that was linked 
Table I PCR-cultured and plasmid control templates and predicted panfungal PCR product/amplicon sizes

\begin{tabular}{|c|c|c|}
\hline PCR template & Template source* & $\begin{array}{l}\text { PCR } \\
\text { amplicon size }\end{array}$ \\
\hline Candida parapsilosis & SRL-FII03 clinical isolate ${ }^{\pi}$ & $311 \mathrm{bp}$ \\
\hline Candida albicans & ATCC 28516 & 338 bp \\
\hline Candida guilliermondii & ATCC 6260 & 379 bp \\
\hline Candida/Yarrowia lipolytica & ATCC 18492 & 242 bp \\
\hline$\left.\mathrm{pCA}\right|^{\S}$ & C. albicans EcoRI rDNA fragment in plasmid pUCI9 & $338 \mathrm{bp}$ \\
\hline
\end{tabular}

Notes: *Source of genomic or plasmid DNA used as PCR control templates; ${ }^{\dagger}$ predicted PCR amplicon size in base pairs according to genome sequence data (GenBank, National Center for Biotechnology Information, National Library of Medicine, Bethesda, MD, USA); ${ }^{\top}$ Candida parapsilosis ocular isolate from the Sid W Richardson Ocular Microbiology Laboratory fungal culture library, Cullen Eye Institute, Baylor College of Medicine, Houston, TX, USA; ${ }^{\S}$ EcoRI restriction endonuclease enzyme fragment including the ribosomal RNA encoding segment of DNA (rDNA) from the ATCC 32354 strain of Candida albicans cloned into the pUCI9 plasmid. ${ }^{17}$

Abbreviations: ATCC, American Type Culture Collection; PCR, polymerase chain reaction.

to intraocular irrigating solutions..$^{27,28}$ This report demonstrates the potential for $C$. parapsilosis to be the etiologic cause of infectious keratitis following insertion of corneal ring segments in the treatment of keratoconus. In addition to its link with the endophthalmitis outbreak and with the current

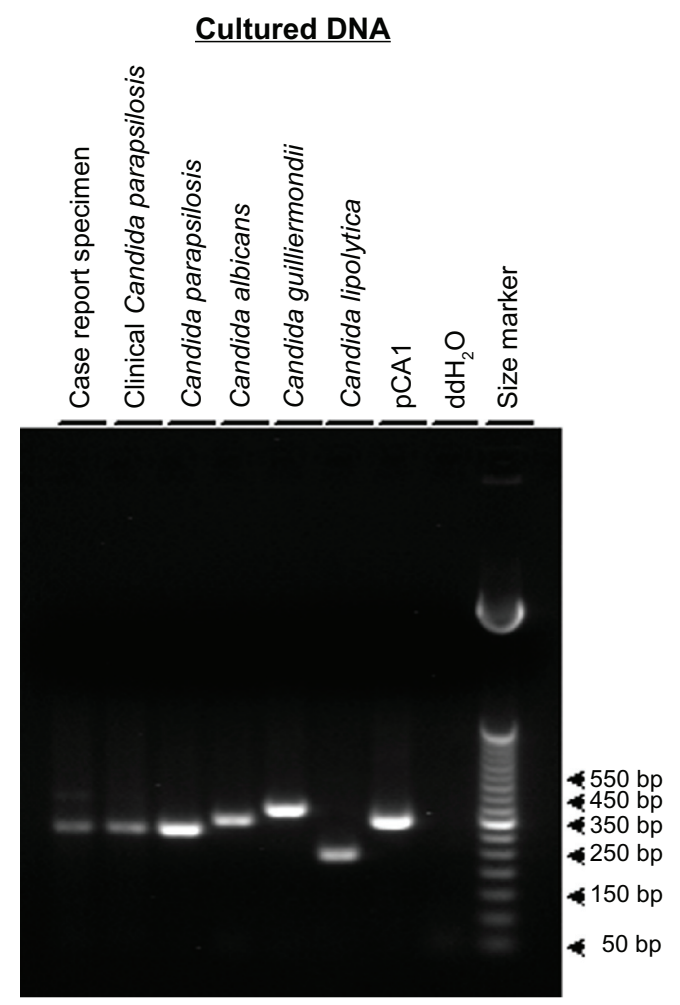

Figure 3 Panfungal polymerase chain reaction analysis.

Notes: Paraffin-embedded corneal specimens and control DNA samples were evaluated using a panfungal polymerase chain reaction assay, electrophoretically resolved on a $1.8 \%$ agarose Tris-borate-EDTA gel, and visualized using ethidium bromide and ultraviolet excitation. DNA extracted from the current case report specimen (lane I), DNA extracted from a confirmed Candida parapsilosis infectious crystalline keratopathy clinical specimen (lane 2), I $\times 10^{4}$ genome equivalents of DNA extracted from cultured C. parapsilosis (lane 3 ), $1 \times 10^{4}$ genome equivalents of DNA extracted from cultured Candida albicans (lane 4), I $\times 10^{4}$ genome equivalents of DNA extracted from cultured Candida guilliermondii (lane 5), I $\times 10^{4}$ genome equivalents of DNA extracted from cultured Candida lipolytica (lane 6), $4 \times 10^{4}$ copies of plasmid pCAI (lane 7), deionized distilled water as a negative control (lane 8), and a 50 bp size marker ladder (lane 9). case, C. parapsilosis has other ophthalmic associations, such as being the most frequently isolated fungal organism from the normal outer eye in a 1969 study in south Florida ${ }^{29}$ and several reports of secondary ophthalmic infections. ${ }^{18,30-38}$ It has also been linked with crystalline keratopathy in a corneal graft $^{18}$ and suppurative stromal keratitis. ${ }^{32,39} \mathrm{~A}$ large case series suggests that $C$. parapsilosis accounts for approximately $10 \%$ of all causes of yeast keratitis in Southern Florida. ${ }^{32}$ Recently, C. parapsilosis has been reported as a cause of chronic postoperative endophthalmitis. ${ }^{28,40}$ Furthermore, C. parapsilosis has emerged as an important nosocomial pathogen with many systemic clinical manifestations in addition to the ocular manifestation of endophthalmitis. ${ }^{41}$ Overall, C. parapsilosis has accounted for $3 \%-27 \%$ of cases of fungemia in large hospital-based studies. ${ }^{41}$ Candida and other yeasts are more frequently opportunistic than are filamentous fungi. ${ }^{42}$ Infections caused by these agents are usually seen in compromised corneas with multiple predisposing alterations in host defense.

Comparison by PCR of the DNA isolated from the current case with various cultured strains of Candida and with previously confirmed $C$. parapsilosis-infected corneal tissue was consistent with the infecting etiologic agent being $C$. parapsilosis. The sensitivity and specificity of any molecular diagnostic approach are important parameters for interpretation of assay results. Establishment of the sensitivity and specificity of the current assay has been previously detailed. ${ }^{17}$ The panfungal primers used bracket a region of the fungal genome encoding the highly conserved 5.8 s ribosomal RNA (rRNA), internal transcribed sequence-2 (ITS-2), and $28 \mathrm{~s}$ rRNA. The sequence specificity and assay stringency conditions allow for sensitive amplification of DNA from a wide variety of fungal strains without amplification of human, bovine, murine, bacterial, or viral DNA. While highly conserved, genomic sequence heterogeneity results in variation of the PCR amplicon/product size depending on 
the specific fungal strain used as a template source. Candida strains produce PCR amplicons ranging in size from $242 \mathrm{bp}$ to $379 \mathrm{bp}$ (Table 1) with C. parapsilosis producing a $311 \mathrm{bp}$ PCR product.

This is the first reported case in the peer-reviewed literature of $C$. parapsilosis keratitis following insertion of intrastromal corneal ring segments. The origin of the Candida, whether from the normal ocular flora or introduced from an exogenous source, is not entirely clear and could not be determined from the current study. While the source is unknown, exposure of the stroma by insertion of Intacs may have allowed ingress of the fungus.

Lipid accumulation on the external side of intrastromal ring segments is common and may complicate the clinical picture of an infectious process. During evaluation of any cornea with intrastromal ring segments, it is important to distinguish between the white color of lipid accumulation and that of an infectious infiltrate. Awareness and consideration of an infectious process being potentially responsible for any white banking is important and may play a critical role in correct diagnosis and subsequent treatment.

Patients should be informed of the risk factors and warning signs of infectious keratitis and should be advised to seek medical attention immediately should they develop signs of symptoms of keratitis. Unlike bacterial keratitis, which can be controlled by potent antibiotics, fungal keratitis is difficult to manage because of the lack of effective antifungal agents, low drug bioavailability, ocular toxicity, decreased solubility, and late presentation with large infiltrates. Long-term postoperative observation following intrastromal corneal ring segments insertion is advocated, especially given that the onset of microbial keratitis post implant can vary from days to months. ${ }^{8,9,11-14,16,43,44} \mathrm{~A}$ high degree of suspicion along with appropriate and complete microbiologic testing, coupled with prompt and appropriate treatment, may result in better visual recovery. This case report adds to the growing and diverse list of organisms and presentations of infectious keratitis following insertion of intrastromal ring segments.

\section{Acknowledgments}

This work was supported in part by grants from the Retina Research Foundation, Houston, Texas, and Research to Prevent Blindness Inc, New York, NY, USA. RLF is the recipient of the Senior Investigator Award from Research to Prevent Blindness Inc.

\section{Disclosure}

The authors report no conflicts of interest in this work.

\section{References}

1. Schanzlin DJ, Abbott RL, Asbell PA. Two-year outcomes of intrastromal corneal ring segments for the correction of myopia. Ophthalmology. 2001;108:1688-1694.

2. Alio J, Salem T, Artola A, Osman A. Intracorneal rings to correct corneal ectasia after laser in situ keratomileusis. $J$ Cataract Refract Surg. 2002;28:1568-1574.

3. Boxer Wachler BS, Christie JP, Chandra NS, et al. Intacs for keratoconus. Ophthalmology. 2003;110:1475.

4. Siganos CS, Kymionis GD, Kartakis N, et al. Management of keratoconus with Intacs. Am J Ophthalmol. 2003;135:64-70.

5. Colin J, Cochener B, Savary G, et al. Correcting keratoconus with intracorneal rings. J Cataract Refract Surg. 2000;26:1117-1122.

6. Colin J, Cochener B, Savary G, et al. INTACS inserts for treating keratoconus: one-year results. Ophthalmology. 2001;108:1409-1414.

7. Kanellopoulos AJ, Pe L, Perry HD, et al. Modified intracorneal ring segment implantations (INTACS) for the management of moderate to advanced keratoconus. Efficacy and complications. Cornea. 2006;25:29-33.

8. Bourcier T, Borderie V, Laroche L. Late bacterial keratitis after implantation of intrastromal corneal ring segments. $J$ Cataract Refract Surg. 2003;29:407-409.

9. Shehadeh-Masha'our R, Modi N, Barbara A, et al. Keratitis after implantation of intrastromal corneal ring segments. J Cataract Refract Surg. 2004;30:1802-1804.

10. Ruckhofer J, Stoiber J, Alzner E, et al. Multicenter European Corneal Correction Assessment Study Group. One year results of European multicenter study of intrastromal corneal ring segments. Part 2: complications, visual symptoms, and patient satisfaction. $J$ Cataract Refract Surg. 2001;27:287-296.

11. Hashemi H, Ghaffari R, Mohammadi M, et al. Microbial keratitis after INTACS implantation with loose suture. $J$ Refract Surg. 2008;24:551-552.

12. Hofling-Lima AL, Branco BC, Romano AC, et al. Corneal infections after implantation of intracorneal ring segments. Cornea. 2004;23:547-549.

13. Ibanez-Alperte J, Perez-Garcia D, Cristobal JA, et al. Keratitis after implantation of intrastromal corneal rings with spontaneous extrusion of the segment. Case Report Ophthalmol. 2010;1:42-46.

14. Levy J, Lifshit T. Keratitis after implantation of intrastromal corneal ring segments (Intacs) aided by femtosecond laser for keratoconus correction: case report and description of the literature. Eur $J$ Ophthalmol. 2010;20:780-784.

15. Mulet ME, Pérez-Santonja JJ, Ferrer C, et al. Microbial keratitis after intrastromal corneal ring segment implantation. J Refract Surg. 2010;26:364-369.

16. Slade DS, Johnson JT, Tabin G. Acanthamoeba and fungal keratitis in a woman with a history of Intacs corneal implants. Eye Contact Lens. 2008;34:185-187.

17. Kercher L, Wardwell SA, Wilhelmus KR, et al. Molecular screening of donor corneas for fungi before excision. Invest Ophthalmol Vis Sci. 2001;42:2578-2583.

18. Rhem M, Wilhelmus KR, Font RL. Infectious crystalline keratopathy caused by Candida parapsilosis. Cornea. 1996;15:543-545.

19. Wright DK, Manos MM. Sample preparation from paraffin-embedded tissues. In: Innis MA, Gelfand DH, Sninsky JJ, White TJ, editors. PCR Protocols: A Guide to Methods and Applications. San Diego, CA: Academic Press; 1990.

20. Mitchell BM, Font RL. Detection of varicella zoster virus DNA in some patients with giant cell arteritis. Invest Ophthalmol Vis Sci. 2001;42:2572-2577.

21. Ausubel FM, Brent R, Kingston RE, et al, editors. Current Protocols in Molecular Biology. New York, NY: John Wiley and Sons; 1995.

22. Yuhasz SA, Dissette VB, Cook ML, et al. Murine cytomegalovirus is present in both chronic active and latent states in persistently infected mice. Virology. 1994;202:272-280. 
23. Kercher L, Mitchell BM. Immune transfer protects severely immunosuppressed mice from murine cytomegalovirus retinitis and reduces the viral load in ocular tissue. J Infect Dis. 2000;182: 652-661.

24. Ferrer C, Alio JL, Montanes AU, et al. Causes of intrastromal corneal ring segment explantation: clinicopathologic correlation analysis. J Cataract Refract Surg. 2010;36:970-977.

25. Miranda D, Sartori M, Francesconi C, et al. Ferrara intrastromal corneal ring segments for severe keratoconus. J Refract Surg. 2003;19: 645-653.

26. Shabayek MH, Alio JL. Intrastromal corneal ring segment implantation by femtosecond laser for keratoconus correction. Ophthalmology. 2007; 114:1643-1652.

27. O'Day DM, Head WS, Robinson RD. An outbreak of Candida parapsilosis endophthalmitis: analysis of strains by enzyme profile and antifungal susceptibility. Br J Ophthalmol. 1987;71:126-129.

28. Fekrat S, Haller JA, Green WR, et al. Pseudophakic Candida parapsilosis endophthalmitis with a consecutive keratitis. Cornea. 1995; 14:212-216.

29. Wilson LA, Aheam DG, Jones DB, et al. Fungi from the normal outer eye. Am J Ophthalmol. 1969;67:52-56.

30. Solomon R, Biser SA, Donnenfeld ED, et al. Candida parapsilosis keratitis following treatment of epithelial ingrowth after laser in situ keratomileusis. Eye Contact Lens. 2004;30:85-86.

31. Muallem MS, Alfonso EC, Romano AC, et al. Bilateral Candida parapsilosis interface keratitis after laser in situ keratomileusis. J Cataract Refract Surg. 2003;29:2022-2025.

32. Rosa RH Jr, Miller D, Alfonso EC. The changing spectrum of fungal keratitis in south Florida. Ophthalmology. 1994;101:1005-1013.

33. Bourcier T, Toueau O, Thomas F, et al. Candida parapsilosis keratitis. Cornea. 2003;22:51-55.
34. Stern WH, Tamura E, Jacobs RA, et al. Epidemic postsurgical Candida parapsilosis endophthalmitis. Clinical findings and management of 15 consecutive cases. Ophthalmology. 1985;92: 1701-1709.

35. McCray E, Rampell N, Solomon SL, et al. Outbreak of Candida parapsilosis endophthalmitis after cataract extraction and intraocular lens implantation. J Clin Microbiol. 1986;24:625-628.

36. Gilbert CM, Novak MA. Successful treatment of postoperative Candida endophthalmitis in an eye with an intraocular lens implant. Am J Ophthalmol. 1984;97:593-595.

37. Stransky TJ. Postoperative endophthalmitis secondary to Candida parapsilosis keratitis. A case treated by vitrectomy and intravitreous therapy. Retina. 1981;1:179-185.

38. Sun RL, Jones DB, Wilhelmus KR. Clinical characteristics and outcome of Candida keratitis. Am J Ophthalmol. 2007;143:1043-1045.

39. Tseng SH, Ling KC. Late microbial keratitis after corneal transplantation. Cornea. 1995;14:591-594.

40. Fox GM, Joondeph BC, Flynn HW Jr, et al. Delayed-onset pseudophakic endophthalmitis. Am J Ophthalmol. 1991;111:163-173.

41. Weems JJ Jr. Candida parapsilosis: epidemiology, pathogenicity, clinical manifestations and antimicrobial susceptibility. Clin Infect Dis. 1992;14:756-766.

42. Tanure MA, Cohen EJ, Sudesh S, et al. Spectrum of fungal keratitis at Wills Eye Hospital, Philadelphia, Pennsylvania. Cornea. 2000;19: 307-312.

43. Chaudhry IA, Al-Ghamdi AA, Kirat O, et al. Bilateral infectious keratitis after implantation of intrastromal corneal ring segments. Cornea. 2010;29:339-341

44. Galvis V, Tello A, Delgado J, et al. Late bacterial keratitis after intracorneal ring segments (Ferrara ring) insertion for keratoconus. Cornea. 2007;26:1282-1284.
Clinical Ophthalmology

\section{Publish your work in this journal}

Clinical Ophthalmology is an international, peer-reviewed journal covering all subspecialties within ophthalmology. Key topics include: Optometry; Visual science; Pharmacology and drug therapy in eye diseases; Basic Sciences; Primary and Secondary eye care; Patient Safety and Quality of Care Improvements. This journal is indexed on

\section{Dovepress}

PubMed Central and CAS, and is the official journal of The Society of Clinical Ophthalmology (SCO). The manuscript management system is completely online and includes a very quick and fair peer-review system, which is all easy to use. Visit http://www.dovepress.com/ testimonials.php to read real quotes from published authors. 